\title{
光回路実装技術委員会の活動を振り返って
}

\author{
杉原 興浩*
}

\section{Looking Back on Activities of Optical Packaging Technology Committee}

Okihiro SUGIHARA*

* 宇都宮大学大学院工学研究科（＝ 321-8585 栃木県宇都宮市陽東 7-1-2)
* Graduate School of Engineering, Utsunomiya University (7-1-2, Yoto, Utsunomiya, Tochigi 321-8585)

\section{1.はじめに}

エレクトロニクス実装学会が発足して今年で 20 周年を迎 える。今でこそ学会内にさまざまな委員会が存在してお り, 光回路実装技術委員会も当然のごとく学会内で主体的 に活動しているが, ここまで活動が盛んになってくるまで には，歴代委員会メンバの弛まぬ技術開発があったことは 間違いなく，まさにメンバの努力の賜物であり，発足当時 の暗中模索していた姿とは雲泥の差がある。今回, 第 1 期 から一委員として光回路実装技術委員会の活動を見続けて きた筆者が, 委員会を代表してその活動変遷について紹介 させていただくことは非常に光栄である。なお，昔の資料 はほとんど手元に残っておらず，委員会メンバも交代が激 しく，歴史を教えてもらえる方もごくわずかになってし まったため, 筆者の記憶に頼る内容が多く含まれること を，「随想」ということでご容赦いただきたい。

\section{2. 光回路実装技術委員会の活動変遷}

表 1 に光回路実装委員会活動の変遷を示す。光回路実装 技術委員会は, 1994 年に産声をあげている。これはエレク トロニクス実装学会の前身であるプリント回路学会時代の ことである。初代委員長は, 千歳科学技術大学初代学長を 務められた佐々木敬介先生（当時慶應義塾大学教授）が就 任した。委員会は, 産官学の光回路・光ファイバの研究者 や技術者の代表メンバ約 20 名から構成されていた。イギリ スにて研究を行なっていた筆者のところにも佐々木教授か らメールが届き, 委員会参加のお誘いを受けてその末席に 加わることになった。プリント回路板や LSI (Large Scale Integration) などの電子を媒体とする電気・電子回路全盛の 時代に「光」という概念がどのように関わるのか, まして や学会はプリント回路中心であり，社会人になって間もな かった筆者には，ピンとくる解を見出せていなかった。と

表 1. 主要な光実装技術委員会活動変遷

\begin{tabular}{|c|c|c|}
\hline 年 & 委員会活動 & 技術動向 ·他 \\
\hline 1994 & 光回路実装技術委員会発足 & プリント回路学会 \\
\hline 1995 & $\begin{array}{l}\text { 講演大会にて最初の光回路実装技術セッション } \\
\text { 学会誌に初の光回路実装技術特集号 }\end{array}$ & \\
\hline 1996 & 絵解き・光回路実装技術入門 & \\
\hline 1998 & 絵解き - 光回路実装技術入門再開講 & エレクトロニクス実装学会発足 \\
\hline 1999 & $\begin{array}{l}\text { 第 } 1 \text { 回 OPT 公開研究会 } \\
2010 \text { 年のエレクトロンク実装技術ロードマップ }\end{array}$ & ASET 光電子 SI 技術プロジェクト \\
\hline 2003 & 光回路実装技術ロードマップ 2003 年度版 & シリコンフォトニクス（黎明期） \\
\hline 2004 & & JPCA 光実装部品標準化 \\
\hline 2005 & 光回路実装技術ロードマップ 2005 年度版 & AOC 市販（この頃） \\
\hline 2006 & 光回路実装技術基礎講座「光配線と電気配線の融合化技術」 & \\
\hline 2007 & & IEC/TC86/JWG9 発足 \\
\hline 2008 & $\begin{array}{l}\text { 光回路実装技術ロードマップ } 2008 \text { 年度版 } \\
\text { 光配線実装技術ハンドブック (三上 修監修) 発刊 }\end{array}$ & アメリカ DARPA プロジェクト \\
\hline 2009 & & PECST プログラム \\
\hline 2010 & 光回路実装技術ロードマップ 2009 年度版 & \\
\hline 2011 & & $\begin{array}{l}\text { PETRA プロジェクト第 } 1 \text { 期 } \\
\text { 光配線搭載 PC 市販 }\end{array}$ \\
\hline 2012 & & 欧州 FP7 プロジェクト \\
\hline 2013 & 光回路実装技術ロードマップ 2013 年度版 & \\
\hline 2014 & & PETRA プロジェクト第 2 期 \\
\hline 2016 & 光回路実装技術ロードマップ 2016 年度版 & \\
\hline 2018 & & PETRA プロジェクト第 3 期 \\
\hline
\end{tabular}


にかく委員会の議論を扯聴することで, 自分の専門である 有機系光導波路が実用に向けてどのようなロードマップを 描けるのかという興味で引き受けてみた（もちろん，恩師 である佐々木先生からの参加要請というところが最大の理 由である)。

委員会発足当時の光実装技術について動向を振り返って みたい。既に光ファイバ通信は1970 年代に実証され， 80 年代に実用化, 90 年代に国際的な光ネットワークが構築さ れている。委員会が直接携わる光導波路についても, その 概念の提唱は 1960 年代であり, 光ファイバ通信ネットワー クを補完する部材で, しかも集積化が可能ということで, 多くの機関で研究開発が進展し, 90 年代に石英系平面光回 路 (PLC: Planar Lightwave Circuit) として普及するようになっ た。また, 光源も伊賀健一先生 (当時東京工業大学) によ る垂直共振器型面発光半導体レーザ (VCSEL: Vertical Cavity Surface Emitting Laser)の発明（1977 年）が90 年代に開花 し, 光通信だけでなくレーザプリンタなどの民生機器に展 開しつつあった。これらの光部品が実用化して身近になる につれて, 光部品を簡便にアセンブリし, モジュール・シ ステム化に対応することが必須になってくると考えられて いた。また, 従来の電気配線の一部に光配線を取り入れ, スーパーコンピュータやデータセンタの機器間・機器内の 情報処理を高速に行うような, 光インターコネクションが 普及するのではないかという議論も始まっていた。そのよ うな雲囲気の中で, 1992 年に内田禎二先生（当時東海大学 教授）が光表面実装技術の概念を提案された。光部品の実 用普及のためには, 多数の光部品を電子部品と一緒に光部 品を効率的にボード上に実装することが必須となり, 現実 的な生産技術との整合を考慮すると, 光表面実装技術が有 力な解となるであろうという期待があった。一方で, 光と 電気の性質の違いや光部品の多様性などが災いし，アライ メントやアセンブリなどの自動化に対する課題がはっきり と見えていた。しかしながら，このような光部品の実装技 術の諸問題を扱い, 分野の発展を支援するような学会・研 究会は皆無であり, 将来実現するであろう光電気融合技術 を視野に入れて, 光回路実装技術を専門に議論できる場が 必要となり, プリント回路学会に光回路実装技術委員会が 立ち上がった。

次に, 委員会活動について振り返ってみる。1995 年 3 月 の第 9 回回路実装学術講演大会では, 初の光回路実装技術 セッションができ, キーノートスピーカの内田禎二東海大 学教授が「光実装技術の展望」と題して光エレクトロニク スにおける実装技術の重要性を講演している。また，5件 の一般講演もあり, 初回でありながら多数の質疑応答があ り，光回路実装技術への関心の高さがうかがわれていた。 また, 同年の回路実装学会誌第 10 巻第 5 号には, 初の「光 回路実装技術」特集が発行されており, 佐々木敬介慶應義 塾大学教授による解説記事「光回路実装技術の動向」のほ
か, 16 編の特集記事が揭載されている。産声をあげた分野 であるが, 将来の開花に向けて, 現状の課題の浮き彫り と, 解決策の提案, さらには将来像まで載っており, 黎明 期にこの分野の第 1 線で活躍されていた著者の皆様の考え を直接語っている特集号であり，20 年以上経た現在読んで も非常に面白い。特筆すべきは，本特集号の内容の多くが その後の光実装技術の発展に寄与しており, 一部は実用に まで至っていることである。その後もさまざまな新規光実 装技術が提案実証されているが，基本コンセプトや技術の 流れは, 絶え間なく続いていると断言できょう。

光回路実装技術については，学会内でもまだ浸透してい なかったため, その啓蒙活動も必要であった。1996 年の回 路実装学会誌第 11 巻第 7 号から, 8 回にわたって, 光回路 実装技術委員メンバの執筆による絵解き・光実装技術入門 が掲載されている。第 1 回から第 8 回までの夕イトルと著 者は以下のとおりである。

*序

第 1 回 光への招待 $/$ 内田禎二 (東海大学) 第 11 巻第 7 号（1996 年 11 月）

第 2 回 光デバイスの実装は何が難しいか? 一光と電気 の違い／中野義昭（東京大学）第 12 巻第 1 号（1997 年 1 月)

*光部品入門

第 3 回 光ファイバ /日高啓視（フジクラ） 第 12 巻第 2 号（1997 年 3 月）

第 4 回 実装技術とマイクロオプティックス／西澤紘一

(職業能力開発大学校) 第 12 巻第 3 号 (1997 年 5 月)

第 5 回 光部品 (LD, PD) / 小山二三夫 (東京工業大学)

第 12 巻第 4 号 (1997 年 7 月)

*光実装の課題

第 6 回 光導波路／栗原 隆(NTT) 第 12 巻第 6 号（1997 年 9 月)

第 7 回 光接続一結合損失とのたたかい／辻 伸二（日 立製作所） 第 12 巻第 7 号（1997 年 11 月）

第 8 回 アライメント一光実装の代名詞／伊藤正隆（日 本電気） 第 13 巻第 1 号 (1998 年 1 月)

光回路実装技術の重要性は高まってきたが, 他方で課題 も山積していた。そこで, 学会内の多くの研究者, 技術者 の力を結集する必要があった。特に, 電子回路の実装で経 験を有する方や, これからの若手研究者に光実装の実態を 理解してもらい, 難題の解決に協力してもらえるようにす ることが必要ということになり, 光実装の概念を多くの読 者に知ってもらうことを目的として企画したものである。 この絵解き・光実装技術入門の企画は，非常に好評であ り, 学会内の電気・電子回路実装に携わっている会員に光 実装への理解が深まったのではないかと実感した。実際に エレクトロニクス実装学会になった 1998 年から, 絵解き・ 光実装技術入門が再開講し, 旧連載に続く形で「モジュー 
ル技術の現状」編と「将来の光実装技術」編の計 6 回を連 載している。

同様に，学会内外で光に関わる最先端技術情報を提供 し, 専門的に技術の意見交換を行う場を提供することを目 的として, 1999 年 1 月には第 1 回光回路実装技術 (OPT: Optical Packaging Technology) 公開研究会を開催している。 OPT 公開研究会は, 年 3 4 回の主催を続けており, 現在 で第 67 回を数える。委員会の主要活動である。

絵解き・光実装技術入門や OPT 公開研究会の効果であろ うか, 1998 年に学会が「2010 年のエレクトロニクス実装技 術ロードマップ」を編集するということで, 光回路実装技 術委員会に参加の打診があった。光回路実装技術や委員会 活動を周知できる千載一遇のチャンスとばかりに, ワーキ ングを重ね,「第 12 章 光回路実装技術」を 24 ページにわ たって執筆した。ロードマップについては, その後は光回 路実装技術委員会単独で編纂することになるが, 光インター コネクションの動向と展望に注力して，ワーキンググルー プを設置し，2３年ごとに社会情勢・技術の変化とともに テーマを設定し，更新を続けている。委員会のもう一つの 主要活動であり,これまでに 6 版を発行している。ロード マップ発刊時期とメインテーマ：提言は以下の通りである。

2003 年度版「光インターコネクション実現への提案と展

望 : 実現構成」

2005 年度版「光インターコネクション進展の可能性：応 用毎の課題」

2008 年度版「光インターコネクション普及の課題と展

望：I/O と配線, $\mathrm{OE}$ 変換の帯域密度」

2010 年度版「光インターコネクション適用領域：高密

度・低電力光配線技術展望, 目標仕様」

2013 年度版「光インターコネクション普及, 適用範囲拡

大 : 信頼性（システム要求, 光部品展望)」

2016 年度版「今後のシステム課題に対応する光インター

コネクション技術 : 光インターフェース形態の進展,

チップスケール光集積実装技術, 低分散光配線技術,

光電気混載基板の形態と実現課題」

学会活動と並行して, この 20 年間に光実装技術を取り巻 く環境の変化についても述べておきたい。1999 年から経済 産業省主導の超先端電子技術開発機構 (ASET) プロジェク 卜に光電気複合実装技術が揭げられ，複数の機関が参画し た。その成果は光配線の重要性を認識するのに大きな役割 を担った。その後も光電気実装に関する大型・小型のプロ ジェクトが続き, 適用範囲も広がって現在に至っている。 並行して, 2004 年から光実装部品標準化もスタートし, 日 本電子回路工業会 (JPCA) の標準化検討委員会（委員長：中 野義昭東京大学教授）において,「光配線板通則」などの規 格が文書化されている。この標準化の流れは現在でも続い ており, 国際電気標準会議 (IEC) の第 86 専門委員会 (TC86) 第 9 共同作業部会 (JWG9) にて光配線に関する各種国際標
準審議が行われている。

このような研究開発や標準化活動を地道に行うことによ り，光実装技術に対する関心も大きく広がった。また，長 距離通信からデータセンタ内の配線に適用出口を見出し, 異なる伝送距離に扔ける各階層での光インターコネクショ ンにさまざまな要素技術が発生することになった。八イエ ンド機器のユニット間の光インターコネクション技術に は，アクティブ光ケーブル (AOC: Active Optical Cable) ${ }^{\dagger}$ が 2000 年代半ばに実用化され，AOC の省電力・省スペース などメリットを活かして爆発的に普及している。対極にあ る超短距離のチップ内光伝送にも，シリコンフォトニクス が提唱され，実用を目指して世界中の研究開発機関がしの ぎを削っている。その中で, 光回路実装技術委員会が OPT 公開研究会やロードマップ執筆で果たしてきた役割は非常 に大きい。この先もモノのインターネット (IoT)などのネッ 卜利用の普及に伴い, 通信トラフィックの伝送容量は増大 する一方であり, 光配線の重要性は十分認識され，その適 用も，より短距離に広がることであろう。

\section{3. おわりに}

24 年にわたる光回路実装技術委員会の活動変遷とその周 辺技術状況を俯瞰してみたが, 黎明期の主要発起人メンバ は，将来ここまで光配線が進展・普及すると予測して設立 したのだろうか? 非常に興味がある。残念ながら，今と なっては打聞きすることも不可能であるが，もし予想が的 中していたのであれば，その慧眼には感服する。また，こ の 24 年間に産学官から多くのメンバが委員となって参画し, 先人の意思を継いで活動を支えてくださった。撒いた種が 開花になるには，時間をかけて丁寧に育てるプロセスが必 要であり，光配線が普及してきた現状こそ皆で育ててきた 成果であろう。とはいえ，光配線が隅々まで普及している わけではなく，まだ三分咲き程度であろうか，この先も新 規実装技術（光に限定せず電気や周辺も含めて）を吸収し て，さまざまな分野で満開になることを見届けていきたい。

(2018.7.26- 受理)

\section{†用語解説}

アクティブ光ケーブル (AOC: Active Optical Cable) : 光 ファイバと光トランシーバを一体化させた製品であ り, データセン夕内などの比較的短距離の大容量デー 夕通信を行うのに適している。

杉原興浩（すぎはら おきひろ）

著者紹介

平 3 慶應義塾大学大学院博士課程了。日本学術振興会, 静岡大学, 東北 大学を経て, 現在宇都宮大学大学院工学研究科（兼担オプティクス教育 研究センター）教授。光学用有機材料ナノ構造制御と光導波路の研究お よび車載光通信標準化開発に従事。平 21 より科学技術振興機構戦略的 イノベーション創出推進プログラム（Sイノベ）「フォトニクスポリマー」 プロジェクトマネージャー。平 25 エレクトロニクス実装学会理事など を歴任。工博。 